\title{
UMĚNÍ, VNÍMÁNÍ A VIZUÁLNÍ MYŠLENÍ V KONTEXTU TEORIÍ RUDOLFA ARNHEIMA
}

\author{
ŠÁRKA JENDRAŠŠÁK \\ Ústav dějin křest’anského umění, Katolická teologická fakulta Univerzity Karlovy; \\ Galerie Rudolfinum \\ E-mail: sjendrassak@gmail.com
}

\begin{abstract}
Art, perception and visual thinking in the context of Rudolf Arnheim's theory

Knowledge of the world and education is traditionally based primarily on reading books, in which the main tool is the language that enables knowledge and education to be passed on to people. Since language is used to naming things and is an established means of communication, we understand it as a tool for interpreting reality, not for self-evaluation of a given reality. In this context, the image, and in our case, the work of art, is an authentic means of sensory communication, which is a direct form of communication, so its meaning is not interpreted in any way, that is, changed or enriched by other connotations and meanings. Sensory perception is thus based on the authentic experience of the recipient and creates the possibilities of language.

German art psychologist Rudolf Arnheim (1904-2007) dedicated his lifelong research to the theories of sensory perception of art that lead to visual thinking. The language of art is understood as an expression medium that acts on the sensory component of human perception and thus creates the true reality of the seen. In this context, he devoted himself to the problem of analyzing the language of art, which he understood as the only authentic approach to reality. Art thus becomes a sovereign means of communication, which brings through the perceptual components a new interpretation of a given reality. Sensory perception of the seen is an active and creative process of comprehension that is composed of invention and intelligence. The characters are structured within the framework of the ten major visual categories that make up the whole of the seen. Art thus reveals the true nature of things and human existence, and that is one of its main roles.

In connection with these theories the devotion to art, whether as a viewer or a theorist, develop our productive thinking and help us better understand the true reality of the world in which we live. This knowledge is authentic because it is based on our own sensory experience. This is not an interpretation or a given interpretation of a thing, but a matter in itself, which primarily affects our visual senses through the empathy, subjectivity, experience, emotions and knowledge of each person. Images are the basic elements that make up the human understanding of the world and without which we would not be able to fully understand human civilization.
\end{abstract}

Keywords: Perception of art; psychology of art; visual thinking; Rudolf Arnheim; viewer

\section{Smyslová percepce umění}

Německý psycholog umění Rudolf Arnheim (1904-2007) zasvětil svůj celoživotní výzkum teorii smyslové percepce umění, která pomáhá rozvíjet abstraktní vizuální myšlení. Jazyk umění chápal jako vyjadřovací prostředek, který působí na smyslovou složku lid- 
ského vnímání a vytváří tak pravou realitu viděného. Jazyk uměleckého díla je tedy řízen smyslovým vnímáním, ve kterém jsou obsaženy všechny naše zkušenosti a které vytváří možnosti mluveného jazyka. K tomu Arnheim uvádí: „Naším jediným přístupem k realitě je smyslový zážitek, tedy zrak, sluch nebo dotek. Smyslový zážitek znamená vždy více než jen vidět nebo se dotýkat. Zahrnuje také mentální obrazy a znalosti, které jsou založené na zkušenosti. A toto všechno vytvárí naše chápání světa. "1 Tato teorie nepopírá význam a důležitost mluveného jazyka jako nástroje komunikace, který je nedocenitelný pro rozvoj lidské existence. Ovšem chceme zdůraznit, že tento typ jazyka je nástrojem pro to, co získáváme skrze vizuální vnímání, přičemž musíme zdůraznit, že vizuální záležitosti nemohou být plnohodnotně vyjádřeny verbálně.

Rudolf Arnheim se narodil v Berlíně v roce 1904 v rodině židovského původu. Studoval psychologii, filozofii, dějiny umění a hudby na Friedrich Wilhelm University v Berlíně. Zájem o psychologii u něj již v raném mládí vzbudily knihy Sigmunda Freuda. Mezi jeho profesory patřili Max Wertheimer a Wolfgang Köhler, kteří se zajímali o Gestalt Psychology (psychologii tvaru, tvarovou psychologii). V roce 1928 ukončil doktorát prací na téma Vztah mezi výrazem tváře a rukopisem člověka.

Ve třicátých letech začíná svou kariéru jako filmový kritik. Na podzim roku 1932, tři měsíce před nástupem nacistů k moci, publikuje esej v Berliner Tagesblatt na téma srovnání knírku Adolfa Hitlera a Charlieho Chaplina. V podstatě se jednalo o politickou satiru. Arnheim k tomu říká: „Přítel, který měl konexe s nacisty, mi řekl: ,Višs, ten tvůj článek mají ve svých dokumentech. Měl bys odsud raději zmizet. 'A krátce na to jsem opravdu odešel. “2 Ve svých vzpomínkách zdůrazňuje, že v té době se střídala jedna vláda za druhou a všeobecně se mělo za to, že nacismus pomine v průběhu půl roku. Mnoho lidí tehdy vnímalo nacistické zlo dost naivně.

V roce 1933 byl zakázán prodej jeho knihy Film as Art a ještě téhož roku se Arnheim odstěhoval do Ríma. Po fašistické radikalizaci Itálie odešel do Anglie, kde pracoval jako překladatel pro BBC, zatímco čekal na přijímací uprchlické vízum do Spojených států. Nakonec v roce 1940 emigroval do USA. Arnheim měl velký vliv na poválečný rozvoj oboru dějin umění a psychologie umění, kde se etabloval jako významný profesor na věhlasných univerzitách - Harvard University, University of Michigan, New School for Social Research New York, Sarah Lawrence College New York. Podařilo se mu obohatit americký akademický svět o evropský pohled doznívající meziválečné a avantgardní éry, což vedlo k jedinečnému spojení kultur a ovlivnění místní intelektuální sféry.

Umění je jedinečný nástroj, který nám umožňuje zkoumat lidské vědomí a fungování lidského mozku a to je jednou z jeho nejpodstatnějších funkcí. V současné době se pozornost většiny vědních oborů, a to nejenom dějin umění, upíná právě k objasňování otázek, jak funguje náš mozek, jak vlastně chápeme a jaká je podstata věcí kolem nás. $\mathrm{V}$ tomto kontextu jsou i v dnešní době teorie Rudolfa Arnheima, které propojují umění s psychologií a teorií o způsobech lidského vnímání, velmi aktuální. Současná věda o mozku dospěla $\mathrm{k}$ mnoha poznatkům, co se týká vnímání obrazu, a můžeme tvrdit, že

\footnotetext{
Uta Grundmann - Rudolf Arnheim, The Intelligence of Vision: An Interview with Rudolf Arnheim, Cabinet II, 2001, č. 7. Dostupné z http://www.cabinetmagazine.org/issues/2/rudolfarnheim.php, vyhledáno 19. 7. 2017. Překlad autorka článku.

2 David A. Pariser, A Conversation with Rudolf Arnheim, Studies in Art Education, A Journal of Issues and Research XXV, 1984, č. 3, s. 179.
} 
je to jedna z nejprozkoumanějších oblastí činností lidského mozku, přičemž velkou roli při těchto výzkumech sehrálo právě umění. Umění rozvíjí vizuální myšlení a stává se tak klíčem lidského poznání. Vizualita je nejpodstatnějším prvkem v procesu chápání, poněvadž poznáváme primárně vizuálně, smysly a zrakem. Díváme-li se na předmět, při způsobu našeho vnímání dochází v mozku k vytvoření mentálního obrazu tohoto předmětu. Charakter mentálního obrazu je ovlivněn, případně dotvořen předešlou zkušeností pozorovatele a jeho archivem vizuální paměti. Nevidíme tedy předmět samotný, ale naši vlastní autentickou projekci - mentální obraz - který je odrazem našeho vědomí, minulých zkušeností a vzdělání. Podstatou vizuálního vnímání je projekce mentálního obrazu. K tomuto postupu získávání významů skrze vizuální vnímání Rudolf Arnheim říká: „Musíme si uvědomit, že percepce organizuje vnímané formy jako optické projekce v oku. Obraz nemůže plnohodnotně přenášet vizuální sdělení do podvědomí bez formy. Jsou to právě tyto organizované formy, nikoliv běžně uživané znaky, které přináší vizuální koncept, jež vytvárí srozumitelnost obrazu. "3 Můžeme tedy říci, že skutečnost a svět kolem nás poznáváme prostřednictvím výsledného mentálního obrazu. Tuto teorii Rudolf Arnheim podrobně rozpracoval ve své knize Art and Visual Perception z roku 1974. Poznávání reality definuje jako hlavní funkci umění: „Považuji umění za prostředek percepce, prostředek poznávání. Percepce umožňuje strukturovat realitu a tím získávat poznatky. Umění nám tak odhaluje pravou podstatu věcí a lidské existence, a to je jedna z jeho hlavních roli.." Veškeré lidské znalosti a snažení vyžadují schopnost pracovat s vizuální představivostí. A nejlepším tréninkem pro rozvíjení těchto schopností je právě umění. Umění rozvíjí abstraktní myšlení, které je sofistikovaným nástrojem lidského poznání a inteligence. V tomto kontextu Arnheim dále rozvíjel problematiku analýzy jazyka umění, který chápal jako jediný autentický přístup k realitě. Umění se tak stává výsostným prostředkem komunikace, který přináší skrze perceptuální složky novou interpretaci dané reality. Smyslové vnímání viděného je aktivní a tvưrčí proces chápání, který je složený z invence a intelektu.

Lidské vnímání je stejně jako umění závislé na struktuře forem a barev. Vidění dává skutečnosti řád, jinými slovy skutečnost strukturuje. Schopnost tvořit kvalitní mentální obrazy spočívá především v dovednosti strukturovat jednotlivé prvky viděného, $\mathrm{z}$ nichž se tento obraz skládá. Abychom mohli snadněji složit celek mentálního obrazu, máme k dispozici několik vizuálních kategorií, jejichž uvědomění si a pojmenování nám umožní lépe chápat a strukturovat viděné. „Percepce spočívá v propojování vizuálních podnětu s př̀dlohami relativně jednoduchých tvarů, které nazývám vizuální koncepty nebo vizuální kategorie. " ${ }^{\text {5 }}$ Mezi tyto vizuální kategorie, a tedy základní prvky lidského vnímání, patří „rovnováha, tvar, forma, růst, prostor, světlo, barva, pohyb, dynamika, výraz“. Přičemž celek viděného je strukturován v rámci těchto deseti hlavních vizuálních kategorií. Rudolf Arnheim tvrdí, že v dokonalém uměleckém díle se nachází těchto deset základních faktorů vizuálních kategorií neboli konceptů, které usnadňují vnímání obrazů. Na základě této své teorie byl Rudolf Arnheim přesvědčen, že smysl života a světa může být přímo vnímán prostřednictvím znaků, tvarů a barev, a proto je přínosné jim věnovat pozornost a studovat je.

Viz Grundmann - Arnheim (pozn. 1). Překlad autorka článku.

Rudolf Arnheim, Art and Visual Perception, Berkeley - Los Angeles - London 1974, s. 6.

Rudolf Arnheim, Visual Thinking, Berkeley - Los Angeles - London 1969, s. 27. Překlad autorka článku. 
Abychom mohli při tvorbě mentálního obrazu kvalitně strukturovat prvky viděného obrazu, je nutné zapojit emocionální složky naší mysli. Tento vědecký objev chtěl Rudolf Arnheim použít v rámci teorií uměnovědy pro lepší porozumění umění při zachování klíčové role subjektivity, intuice a sebevyjádření či sebeprojekce. Jedním z podstatných rysů tohoto druhu interpretace uměleckého díla, potažmo skutečnosti, je tedy propojení emocionálního a intelektuálního faktoru. Samotné vidění je subjektivní využívání tvarů a významů vyskytujících se v realitě. Role subjektivity diváka je v teorii vnímání tak významná, jelikož charakter výsledného mentálního obrazu je závislý na rozsahu vlastních vědomostí diváka, a tak se může stát, že dva různí jedinci vidí stejnou věc odlišně. $\mathrm{Na}$ základě těchto poznatků se domníváme, že významnou roli v procesu vnímání hraje především schopnost empatie jako hlavní nástroj subjektivity. Empatie je smyslová reakce vcítění se, která je primárně nutná pro zásadní dovednost rozpoznání tématu a nálady uměleckého díla.

Svou teorii vnímání umění přibližuje Rudolf Arnheim na příkladu smyslového zážitku při pozorování Rembrandtových pláten: „Svět, kterému se přibližujeme, když se díváme na Rembrandtovy malby, nikdy nebyl prezentován nikým jiným, a abychom do tohoto světa vstoupili, musíme porozumět konkrétní náladě a charakteru jeho světel a stínů, tvárí a gest jeho postav a přístupu $k$ životu, který je tím vším vyjádřen. To vše můžeme získat skrze bezprostřednost našich smyslů a pocitů. Slova mohou počkat a musí počkat, než si naše mysl vezme z jedinečnosti zážitku obecně platné hodnoty, které mohou být pochopeny, strukturovány a seřazeny našimi smysly. Pojmenovat takové obecnosti v uméleckém díle není jednoduché, ale není to tak odlišné od principu, který se snaží popsat povahu jiných komplexních věcí, jako napríklad fyzickou nebo mentální strukturu žijících bytostí. Umění je výtvor organismu, a tak pravděpodobně není o nic méně komplexní než organismus samotný. Často se stává, že vidíme nebo cítíme určité kvality uměleckého díla, ale neumíme je vyjádřit slovy. Dưvod tohoto nezdaru nespočívá v užití jazyka, ale v tom, že ještě nejsme úspěšní v zařazování těchto vnímaných kvalit do vhodných kategorií. Jazyk to nemůže učinit prímo za nás, protože neexistuje žádná př́má cesta smyslového kontaktu a reality, jazyk slouží jen k pojmenování toho, co vidíme, slyšíme nebo si myslíme. V žádném př́ipadě to není cizí médium, nevhodné pro perceptuální záležitosti. " ${ }^{6}$ Musíme si však uvědomit, že konkrétní kvality zážitku $\mathrm{z}$ Rembrandtovy malby jsou jen částečně zjednodušeny na popis a vysvětlení.

Výsledky našeho vnímání je třeba dále formulovat, pojmenovávat, interpretovat a strukturovat. Poznávání světa a vzdělávání je tradičně založeno především na psaném slově, jehož hlavním nástrojem je jazyk, který umožňuje předávat znalosti a vzdělání. Jelikož jazyk slouží k pojmenování věcí a je ustanoveným prostředkem komunikace, je třeba ho chápat jako nástroj interpretace reality, nikoliv vlastního vyhodnocení dané skutečnosti. $\mathrm{V}$ tomto kontextu obraz, a v našem př́padě umělecké dílo, je autentický prostředek smyslové komunikace, který je přímou formou sdělení, tudíž jeho význam není nijak interpretován, to znamená změněn či obohacen o další konotace a významy, ale je vytvářen autenticky v mysli diváka. Smyslové vnímání je tedy založeno na autentické zkušenosti recipienta a vytvárí možnosti jazyka.

6 Arnheim (pozn. 4), s. 2. Překlad autorka článku. 
Víme již tedy, že vnímání je strukturované a má svůj řád. Podstatou obrazu je jeho schopnost sdělovat významy skrze smyslový prožitek. Znaky a jazyk jsou ustanovené jako koncepční modifikátory (conceptual modifiers), to znamená, že tvoří vnější strukturu pro skutečný význam, zatímco vnitřní strukturu významu si vytváří divák ve své mysli pomocí vizuálního vnímání a vytváření mentálních obrazů, tedy vizuálního myšlení. Umělecké dílo je významnou formou vizuálního myšlení a umění je způsob, jak porozumět světu: „Obrazy jsou základním principem, který umožňuje porozumění světu. Vidění a vnímání nejsou pasivní procesy, které jen zaznamenávají realitu. Vidèní a vnímání je aktivní a tvưrčí porozumění, ve smyslu vytváření významů, tedy myšlení. "7

Rudolf Arnheim se zabýval především podmínkami divákova pochopení obrazu v průběhu percepce, jinými slovy, proč předmět (potažmo umělecké dílo) vypadá, tak jak vypadá. V kontextu své teorie vnímání si všímá, jak málo pozornosti je této problematice věnováno: „Umění je opomíjené, protože je založené na vnímání a vnímání je opovrhované, protože se nepredpokládá, že obsahuje myšlenky. Ve skutečnosti predstavitelé vzdělávacího systému nedokážou odůvodnit, proč nepřiznat umění důležitou úlohu, dokud nebudou chápat to, že umění je nejsilnějším prostředkem pro posílení perceptuální složky, bez které by nebylo možné rozvíjet produktivní myšlení v žádné oblasti lidského úsilí."8 Je podstatné si uvědomit, že myšlení je spojeno s obrazy, obrazy obsahují myšlení a umění v nás myšlenky rozvíjí a vyvolává. $V$ př́ípadě současného umění je tato charakteristika zřejmě nejtrefnější, jelikož současní autoři často ve svých dílech reagují na aktuality ze svého okolí a ty pak mohou v divácích vyvolat otázky či přinejmenším hlubší zamyšlení, jež může posunout řešení a vnímání dané problematiky v každodenním životě.

Po představení základních bodi̊ Arnheimovy teorie vizuálního vnímání si přibližme podstatu metody a praktické užití interpretace uměleckých děl. Jestliže chceme pochopit umělecké dílo, musíme ho nazírat v jeho komplexnosti jako celek nálady barevnosti a dynamiky tvarů. Než začneme identifikovat jednotlivé prvky, všímáme si celkové kompozice, která vytvárí dojem, poslání a sdělení, které nesmíme minout. Hledáme téma, klíč, se kterým vše souvisí. Bezpečně vedeni strukturou celku se poté snažíme rozeznat hlavní rysy, znaky a charakteristiky a prozkoumat jejich moc nad souvisejícími detaily. Postupně se odhalí celé bohatství díla, a pokud ho vnímáme správně, začne vydávat své poselství, a to ve spojení se silou naší mysli. Tento průzkum formálních mechanismů neslouží jako náhrada spontánní intuice, ale jako její ztvárnění, které posiluje sdílnost jednotlivých prvků díla. Vytvořením vizuálních kategorií, odhalením skrytých principů a ukázáním strukturálních vztahů a souvislostí v díle se nám podaří najít obohacující významy, které v sobě umělecké dílo skrývá.

\section{For Your Eyes Only}

Arnheimova několikaletá vědecká práce zabývající se teorií vizuálního myšlení a percepcí umění vyústila $\mathrm{v}$ praktické konkrétní příklady interpretace uměleckých děl. Z korespondence Rudolfa Arnheima s Williamem Burbackem, ředitelem bostonského muzea

Arnheim (pozn. 5), s. 8. Překlad autorka článku.

Arnheim (pozn. 4), s. 3. Překlad autorka článku. 
výtvarného umění, vyplývá, že Arnheim zamýšlel projekt s názvem For Your Eyes Only, který měl sloužit jako praktická ukázka aplikování jeho teoretické metody vnímání umění v praxi. V dopise z 12. května 1984 Arnheim rozvádí svůj záměr vybrat dvacet pět děl ze sbírky muzea, které by doplnil o svůj teoretický výklad. Zdůrazňuje, že nejsou primárně podstatné limitující doplňkové faktické informace o díle, mezi něž řadí provenienci, autora, dataci, stylové či geografické zařazení. To, co staví na první místo, je "př́mé čtení vizuálních podnětư". Své komentáře prezentuje ve formě odpovědí na otázky typu: „Co vidíme?" nebo „Jaký přesný význam ustanovují tvary a barvy, uspořádání a prostor?“; „Co dílo představuje?", přičemž „formální charakteristiky nebudou nahliženy podle jejich primárního významu, ale jako prostředky, kterými umělec vyjadřuje nedílné poselství životní zkušenosti".

Dále v dopise přiznává, že interpretovaná díla jsou subjektivním výběrem autora a jediným kritériem výběru byl specifický druh zkušenosti a estetického zážitku, jakým na něj zapůsobila. Cílem této publikace nebylo vytvořit reprezentativní katalog systematicky mapující mistrovská díla sbírky, ale „propiojčit,pomocné oko těm, kteři by rádi blíže poznali, na co se soustředit před uměleckým dílem “. ${ }^{10}$ Dále zdůrazňuje, že kniha podobného typu a ambicí dosud nebyla žádným muzeum umění publikována. Přestože celý projekt dosáhl finální fáze a Rudolf Arnheim měl již veškeré texty připravené, nepodařilo se projekt realizovat, a to $\mathrm{z}$ finančních důvodů.

Po neúspěchu původního plánu znovu seznamuje v dopise z 22. září 1986 nového ředitele muzea Jana Fonteina s projektem publikace. Jako hlavní argument uvádí, že „stále vidí pretrvávající nedostatek pomoci tisícưm lidí, kteři čelí uměleckým dílưm, aniž by věděli, jak vizuálně zpracovat to, co vidí. ${ }^{11}$

Přes veškeré snahy $\mathrm{k}$ vydání publikace nedošlo, jak se dozvídáme $\mathrm{v}$ dalším dopise Williamu Burbackovi z 28. července 1989, kde Arnheim uvádí: „Stále si pohrávám s myšlenkou vydání jednostránkových interpretací, které jsem pro vás napsal během príprav knihy, která nikdy nevyšla. Pravděpodobně některé z nich zařadím do sbírky svých textü a esejí."12

Nakonec bylo použito šest interpretací děl z bostonské sbírky v knize To the Rescue of Art, která vyšla v roce 1991. Příznačný název svědčí o kritickém postoji k vývoji umění na sklonku tisíciletí. Patří do stejného duchu diskusí, v jehož rámci také Hans Belting vydává v roce 1983 svou slavnou esej Konec dějin umění a souběžně také Arthur C. Danto práci Konec umění. Můžeme předpokládat, že Rudolf Arnheim reagoval na aktuální vývoj světa umění a kultury a snažil se přivést diváky k porozumění uměleckému dílu. Bohužel však, jak vyplývá z korespondence, jeho záměr nebyl vyslyšen a př́iliš pochopen jeho kolegy ze světa institucionálního prostředí. Poselství Rudolfa Arnheima můžeme vidět v jeho jasné snaze zahrnout subjektivitu a roli emocí při interpretaci uměleckých děl mezi legitimní přístupy historika umění, které otevírají nové cesty k zaujetí současného diváka. Lidská

9 Překlad autora, dopis Rudolfa Arnheima z 12. května 1984 Williamu Burbackovi. Rudolf Arnheim papers, [undated] and 1932-1992, Archives of American Art, Smithsonian Institution.

10 Překlad autora, dopis Rudolfa Arnheima z 12. května 1984 Williamu Burbackovi. Rudolf Arnheim papers, [undated] and 1932-1992, Archives of American Art, Smithsonian Institution.

11 Překlad autora, dopis Rudolfa Arnheima z 22. záŕí 1986 Janu Fonteinovi. Rudolf Arnheim papers, [undated] and 1932-1992, Archives of American Art, Smithsonian Institution.

12 Překlad autora, dopis Rudolfa Arnheima z 28. července 1989 Williamu Burbackovi. Rudolf Arnheim papers, [undated] and 1932-1992, Archives of American Art, Smithsonian Institution. 
podstata je založena na subjektivním vnímání, jež samo umožňuje opodstatnit roli subjektivity a empatie v kontextu vizuálního myšlení a vnímání uměleckých děl.

\section{Poděkování}

Výzkum, jehož výsledkem je tento příspěvek, byl umožněn díky finanční podpoře Grantové agentury Univerzity Karlovy v rámci grantového projektu č. 1508417 s názvem Změny percepce obrazu v současné společnosti, řešeném během doktorského studia na Katolické teologické fakultě UK.

\section{LITERATURA}

Rudolf Arnheim papers, [undated] and 1932-1992, Archives of American Art, Smithsonian Institution. Rudolf Arnheim, Visual Thinking, Berkeley - Los Angeles - London 1969.

Rudolf Arnheim, Art and Visual Perception, Berkeley - Los Angeles - London 1974.

Dopis Rudolfa Arnheima z 12. května 1984 Williamu Burbackovi. Rudolf Arnheim papers, [undated] and 1932-1992, Archives of American Art, Smithsonian Institution.

Uta Grundmann - Rudolf Arnheim, The Intelligence of Vision: An Interview with Rudolf Arnheim, Cabinet II, 2001, č. 7. Dostupné z http://www.cabinetmagazine.org/issues/2/rudolfarnheim.php, vyhledáno 19. 7. 2017.

David A. Pariser, A Conversation with Rudolf Arnheim, Studies in Art Education, A Journal of Issues and Research XXV, 1984, č. 3, s. 176-184. 